\title{
Dental students' knowledge and attitudes toward patients with epilepsy
}

\author{
Isabella Christina Costa Quadras*; Rafael Zancan Mobile**; Ana Clélia Roussenq**; Melissa Rodrigues \\ de Araujo ${ }^{* * *}$; Maria Ângela Naval Machado***; Antonio Adilson Soares de Lima***
}

* Undergraduate in Dentistry, Department of Stomatology, Federal University of Paraná

** MSc in Dentistry, Department of Stomatology, Federal University of Paraná

*** PhD, Professor of Dentistry, Department of Stomatology, Federal University of Paraná

Received May 04, 2020. Approved February 10, 2021.

\begin{abstract}
Epilepsy is defined as a group of symptoms resulting from several neuronal complications ranging from changes in consciousness and motor activity to sensory phenomena and aberrant behaviors. This health problem has been associated with cases of stigma that can seriously affect the patient's quality of life. This study's main objective was to investigate the knowledge and attitudes regarding the treatment of patients diagnosed with epilepsy by undergraduate dentistry students. The methodology was based on applying a structured questionnaire with 17 close-ended questions that evaluated information such as sociodemographic data, knowledge about epilepsy and social tolerance. The sample consisted of 397 students enrolled in the Dentistry course at Federal University of Paraná and divided into: group 1, students attending the 1st to the 7th semester of the course, and group 2, students in the last semester of the course. Group 1 students had more opportunities to care for patients with epilepsy than group 2. Most students expressed positive attitudes toward living with people suffering from epilepsy and considered that they could not exercise certain professional activities. The question with the least number of correct answers dealt with the treatment of patients with the disease. Students' knowledge of epilepsy was low. However, the level of positive attitudes toward living with this type of patient was considered high.
\end{abstract}

Descriptors: Epilepsy. Knowledge. Social Stigma. Dental Students. Surveys and Questionnaires. 


\section{INTRODUCTION}

Epilepsy is defined as a group of neurological disorders characterized by attacks of varying duration and intensity, ranging from short-lived and virtually imperceptible episodes to long periods of vigorous agitation. In epilepsy, attacks tend to be recurrent and have no definite underlying cause. On the other hand, attacks that occur due to a specific cause are not considered to be representative of epilepsy ${ }^{1,2,3}$.

In most cases of epilepsy, the origin of the disease is unknown. However, some patients develop this condition after brain damage, stroke, brain tumors, drug addiction, or alcoholism, among others. Epileptic seizures are the result of excessive and abnormal nerve cell activity in the cerebral cortex. The diagnosis usually involves excluding other conditions that may cause similar symptoms (such as syncope) and understanding any immediate causes. Epilepsy is often confirmed through an electroencephalogram ${ }^{2}$.

Epilepsy is a clinical condition that cannot be cured, although attacks can be controlled with medication in about $70 \%$ of cases. In people whose attacks do not respond to medication, surgery, neurostimulation, or diet changes may be considered. Not all cases of epilepsy last throughout life, and there is a significant number of people who improve to the point where they no longer need any medication ${ }^{4}$.

Around $1 \%$ of the world population (65 million people) is believed to suffer from epilepsy $^{5}$. The occurrence of epilepsy becomes more common as age advances ${ }^{6,7}$. In developed countries, new cases are more frequent in children and the elderly, while in developing countries it is more frequent in older children and young adults. Between 5 and $10 \%$ of all people will have an attack without a definite cause until the age of 80 , with the probability of suffering a second attack between 40 and 50\%. In different parts of the world, driving permits are restricted or prohibited for people with epilepsy, although many may drive again after a certain period without attacks ${ }^{8-13}$.

Several factors can trigger epileptic seizures during dental care. In some cases, the cause can be significantly associated with anxiety or sleep deprivation, fatigue, and hyperventilation. Those looking for dental surgeons who specialize in special patients often have coexistent neurological or developing conditions associated with epilepsy, or are taking medication that can lower the seizure threshold, such as psychotropic drugs, tricyclic antidepressants, recreational drugs, or alcohol abuse. The often random nature of epileptic seizures makes the chance of their occurrence during a dental appointment relatively low. Seizures have been reported to be the third most common medical adverse event among general dentist surgeons. However, as the general incidence among all types of events was 0.7 per dentist per year, seizures in this context are rare.

However, as there is still much controversy on this subject, it ends up being the target of many prejudiced behaviors. Stigma continues to be an unfortunate consequence of epilepsy worldwide. The aim of this study was to investigate the knowledge and behavioral attitudes of students in the Dentistry Course at Federal University of Paraná (UFPR) concerning the management of patients with epilepsy.

\section{MATERIALS AND METHODS}

This study was approved by the Research Ethics Committee of the Health Sciences Sector of UFPR under Registration number 2.725.253. This cross-sectional observational study included a sample of 397 participants, of both sexes, over 18 years old and regularly enrolled in the UFPR dentistry course, between the $1^{\text {st }}$ and the $9^{\text {th }}$ period of graduation. Data collection took place in the second semester of 2018. All participants 
signed the Free and Informed Consent Form, and the data collection took place inside the classrooms.

The data was collected from the information contained in a questionnaire containing 17 closed questions, which evaluated the following information: sociodemographic data, seven questions regarding knowledge about epilepsy, and seven questions involving stigma / social tolerance. This instrument was developed based on the study developed by Aragon et al. ${ }^{17}$. The data were tabulated in a spreadsheet on Excel for Windows. The sample was divided into two groups, with the first group represented by the students of the last year of the course $\left(8^{\text {th }}\right.$ and $9^{\text {th }}$ semesters) and the second group represented by students from the first seven periods of the course ( $1^{\text {st }}$ to $7^{\text {th }}$ semesters).

Statistical analysis was performed using the Statistical Package for Social Sciences software (SPSS version 20.0, IBM Inc., Chicago, IL, USA). Results were considered significant if $\mathrm{P}$-values were less than 0.05 and the confidence interval was established at $95 \%$. The Chi-square, Fischer Exact, and Mann-Whitney U tests were used to compare the groups.

\section{RESULTS}

The sample consisted of 397 participants with an average age of 21.7 (18 - 38) years of life. Table 1 shows the distribution of the sample according to sex and the period of the course in which the participant was.

Table 2 shows the distribution of answers to the seven questions about some students' attitudes toward epilepsy. The first question demonstrated that most students do not know people who suffer from epilepsy. However, the number of students from the last periods of the course who claimed to know someone suffering from this disease was significantly higher $(p>$ 0.01). On the other hand, students in the first years of the course had more opportunities to care for patients with epilepsy than those in the last year. The other five questions in the questionnaire dealt with issues related to the stigma that the disease carries. Most of the students interviewed showed positive attitudes toward living with people who have epilepsy. However, the majority considered that people with epilepsy could not engage in specific professional activities.

Table 3 shows the distribution of correct and wrong answers related to students' knowledge regarding the disease's etiology, frequency, clinical characteristics, and management. Most students answered six of the seven questions incorrectly. The question in which the least number of correct answers was regarding treating patients with the disease. Only the question that investigated the interviewee's conduct facing an epileptic seizure in the dental chair presented more correct answers, regardless of the student's period. An interesting fact was observed when comparing the number of correct answers concerning the interviewee's period. Students who were in the last year of the course had less knowledge about epilepsy than those from previous periods. There was a statistically significant difference in the answers given to the question investigating which local anesthetic was the most recommended to be used in patients with epilepsy. However, most students from the first to the seventh period were incorrect when answering the question related to the correct use of local anesthetic in patients with epilepsy.

Table 4 presents the answers given to four statements that investigated the interviewees' knowledge and attitudes toward the disease. Most respondents believe that the clinical examination is sufficient to identify patients who have epilepsy. The results also revealed that 40 percent of students, including upper-level students, do not feel safe to care for patients diagnosed with epilepsy. 
Table 1. Demographic data of dentistry students

\begin{tabular}{ll}
\hline Variables & $\mathbf{N}(\mathbf{\%})$ \\
\hline Gender & \\
Male & $86(21.7)$ \\
Female & $299(75.3)$ \\
Not answered & $12(3.0)$ \\
Course Period & \\
$1-7$ & $298(75.1)$ \\
$8-9$ & $98(24.7)$ \\
Not answered & $01(0.3)$ \\
\hline
\end{tabular}

Table 2. Distribution of dentistry students' attitudes toward epilepsy according to the course periods

\begin{tabular}{cccc}
\hline Questions & \multicolumn{2}{c}{$\mathbf{N}(\%)$} & P-value \\
\cline { 2 - 3 } & Yes & No & \\
\cline { 1 - 2 } Do you know or have you ever met someone & who suffers from epilepsy? \\
$8-9$ & $46(46.9)$ & $52(53.1)$ & $* \mathbf{0 . 0 1 0}$ \\
$1-7$ & $96(32.4)$ & $200(67.6)$ & \\
Have you ever witnessed someone suffering & from an epileptic seizure? \\
$8-9$ & $25(25.5)$ & $73(74.5)$ & $* 0.746$ \\
$1-7$ & $81(27.2)$ & $217(72.8)$ &
\end{tabular}

Would you accept if a close relative were in school or working with someone with epilepsy?
8-9
94 (97.9)
$2(2.1)$
$* * 0.600$
$1-7$
$293(99.0) \quad 3(1.0)$

Would you agree if a close relative were to marry someone with epilepsy?
8-9
$97(99.0)$
$1(1.0)$
$* * 1.000$
$1-7$
292 (98.6)
$4(1.4)$

Do you think people with epilepsy can have children?
8-9
94 (97.9)
$2(2.1)$
$* * 0.682$
$1-7$
$290(98.3) \quad 5(1.7)$

Do you think people with epilepsy can work in any activity?
8-9
$44(44.9)$
$54(55.1)$
$* 0.580$
$1-7$
$141(48.1)$
$152(51.9)$

Have you seen any patients with epilepsy at the clinic?
8-9
4 (4.1)
94 (95.9)
$* * 1.000$
1-7
$12(4.0)$
$285(96.0)$

* Chi-squared test

** Fisher's exact test

Statistical significance when $\mathrm{p}<0.05$ 
Table 3. Distribution of knowledge of dental students concerning epilepsy according to the periods of the course

\begin{tabular}{|c|c|c|c|}
\hline \multirow[t]{2}{*}{ Questions } & \multicolumn{2}{|l|}{$\mathbf{N}(\%)$} & \multirow[t]{2}{*}{ P-value } \\
\hline & Correct & Incorrect & \\
\hline \multicolumn{4}{|c|}{ Frequency of epilepsy } \\
\hline $8-9$ & $41(41.8)$ & $57(58.2)$ & \multirow[t]{2}{*}{$* 0.657$} \\
\hline $1-7$ & $110(39.3)$ & $170(60.7)$ & \\
\hline \multicolumn{4}{|c|}{ Cause of epilepsy } \\
\hline $8-9$ & $2(2.0)$ & $96(98.0)$ & \multirow[t]{2}{*}{$* * 1.000$} \\
\hline $1-7$ & $8(2.7)$ & $289(97.3)$ & \\
\hline \multicolumn{4}{|c|}{ What characterizes an epileptic seizure } \\
\hline $8-9$ & $31(31.6)$ & $67(68.4)$ & \multirow[t]{2}{*}{$* 0.417$} \\
\hline $1-7$ & $81(27.4)$ & $215(72.6)$ & \\
\hline \multicolumn{4}{|c|}{ Epilepsy treatment } \\
\hline $8-9$ & $5(5.1)$ & $93(94.9)$ & \multirow[t]{2}{*}{$* * \mathbf{0 . 0 2 5}$} \\
\hline $1-7$ & $3(1.0)$ & $293(99.0)$ & \\
\hline \multicolumn{4}{|c|}{ What to do about an epileptic seizure at the dental chair } \\
\hline $8-9$ & $11(11.2)$ & $87(88.8)$ & \multirow[t]{2}{*}{$* 0.528$} \\
\hline $1-7$ & $27(9.1)$ & $271(90.9)$ & \\
\hline \multicolumn{4}{|c|}{ Local anesthetic recommended for patients with epilepsy } \\
\hline $8-9$ & $64(65.3)$ & $34(34.7)$ & \multirow[t]{2}{*}{$* 0.001$} \\
\hline $1-7$ & $92(44.7)$ & $114(55.3)$ & \\
\hline
\end{tabular}

Table 4. Distribution of answers about dentistry students' knowledge and attitudes toward epilepsy

\begin{tabular}{|c|c|c|c|c|}
\hline \multirow[t]{2}{*}{ Questions } & \multicolumn{3}{|l|}{$\mathbf{N}(\%)$} & \multirow[t]{2}{*}{ P-value } \\
\hline & Agree & Disagree & Do not know & \\
\hline \multicolumn{5}{|c|}{ Medical history and physical examination do not identify all patients with epilepsy. } \\
\hline $8-9$ & $43(43.9)$ & $40(40.8)$ & $15(15.3)$ & $* 0.048$ \\
\hline $1-7$ & $108(36.4)$ & $107(36.0)$ & $82(27.6)$ & \\
\hline \multicolumn{5}{|c|}{ My family would be worried if they knew that I treat patients with epilepsy. } \\
\hline $8-9$ & $3(3.1)$ & $86(87.8)$ & $9(9.2)$ & $* 0.326$ \\
\hline $1-7$ & $18(6.0)$ & $243(81.5)$ & $37(12.4)$ & \\
\hline \multicolumn{5}{|c|}{$\begin{array}{l}\text { Ifeel capable and confident to provide dental treatment to a patient suffering from } \\
\text { epilepsy. }\end{array}$} \\
\hline $8-9$ & $30(30.6)$ & $39(39.8)$ & $29(29.6)$ & $* 0.156$ \\
\hline $1-7$ & $65(21.8)$ & $121(40.6)$ & $112(37.6)$ & \\
\hline \multicolumn{5}{|c|}{$\begin{array}{l}\text { Other patients may be uncomfortable if they discover that I am treating patients with } \\
\text { epilepsy. }\end{array}$} \\
\hline $8-9$ & $0(0.0)$ & $88(89.8)$ & $10(10.2)$ & $* 0.007$ \\
\hline $1-7$ & $9(3.0)$ & $225(75.5)$ & $64(21.5)$ & \\
\hline
\end{tabular}

* Chi-squared test

Statistical significance when $\mathrm{p}<0.05$ 


\section{DISCUSSION}

Epilepsy is a treatable disease with a risk of mortality ${ }^{1^{4}}$. The literature has revealed that patients with epilepsy are at a higher risk for suffering from some type of injury due to epileptic seizures. A systematic review showed that $52 \%$ of patients had soft tissue injuries on the face, $18 \%$ suffered dental trauma and $12 \%$ suffered a maxillofacial fracture ${ }^{15}$. Thus, the dentist needs to be prepared to manage this type of patient and the injuries associated with epileptic seizures.

Lack of knowledge and negative attitudes toward epilepsy have been observed among university students ${ }^{16}$. On the other hand, some studies have revealed conflicting data regarding knowledge about epidemiology, causes, treatment and recognition of epilepsy among dental surgeons ${ }^{1^{7}}{ }^{1{ }^{8}}$. The present study investigated the knowledge and behavioral attitudes of the students of the Dentistry Course at UFPR in relation to the management of patients with epilepsy. The results revealed that students' knowledge of this disease was low, even in those of the course's most advanced periods. On the other hand, positive attitudes toward living with this type of patient were considered high.

The dental management of patients with epilepsy has not always been included in the syllabus of dentistry courses in Brazil. The present study results revealed that questions related to the etiology, frequency, clinical conduct, and clinical characteristics of an epileptic seizure were answered incorrectly by students from all periods of the Dentistry course at UFPR. This result can be explained by the fact that students know little about the subject, as the dental management of patients with this condition is only taught in an optional discipline that is offered to students in the last year of the course. This discipline, called advanced therapy, is offered every six months during the undergraduate course in Dentistry at UFPR for a maximum number of 12 students.

The question with the greatest number of wrong answers concerns the treatment of the disease. Although the treatment of epilepsy is not the function of the dentist, he needs to know this disease. Different drugs are used to treat patients with epilepsy, but some can cause oral changes. Carbamazepine (antiepileptic) is a drug with the potential to cause gingival hyperplasia ${ }^{19}$.

Most students replied that they do not know anyone with the disease and have never seen epileptic seizures. These results corroborate the findings of Hassona et al. ${ }^{16}$, who carried out a similar study in a population of students in the Dentistry course at the University of Jordan. The last year students have already taken more clinical disciplines, which allows contact with many patients. This fact allows more opportunities for the student to assist a patient with some systemic impairment. Thus, a more significant experience in the clinic can explain the high number of students from the most advanced periods of the course who said they knew people with epilepsy, who had greater knowledge about the drug treatment of epilepsy and the local anesthetic indicated to treat patients with epilepsy, when compared to students of the first years.

No senior year student agreed that other patients could be uncomfortable if they knew that they care for others with epilepsy. This finding suggests that these students develop more efficient ethical attitudes than other students, in the sense of not causing the exposure of epileptic patients to others.

Negative attitudes toward epilepsy were observed in some students' responses from both groups, as they would disagree that close relatives should marry or have a relationship with someone with epilepsy. These findings were also 
observed in the research carried out among Jordanian dental students ${ }^{16}$ and Turkish medical students $^{20}$. On the other hand, positive attitudes in managing patients with epilepsy and greater social tolerance have been observed among professionals in some countries such as India and Canada.

As for the stigma of the disease, the questioning that generated the largest number of negative responses investigated the interviewees' opinion in relation to the patient with epilepsy can work in any activity. For most dental students, the patient with this disease could not work in any activity. This information is yet another myth involving epilepsy. However, other studies have also identified negative attitudes toward people with epilepsy and their profession. According to the opinion of no. 53/15 of the Federal Council of Medicine, the granting of a National Driver's License to candidates with epilepsy may be released following the provisions of Law no. 9.503 / 1997 and in CONTRAN Resolution No. 267/2008. In this opinion, the patient with epilepsy who uses antiepileptic medication will be able to drive if he is one year without an epileptic seizure - data that must be presented through a medical report. If the patient is withdrawing from antiepileptic medication, he can drive if he has had epileptic seizures for at least two years and has been without medication and seizure for another six months. On the other hand, driving motorcycles is prohibited.

Despite the knowledge about epilepsy being taught during the last semesters to some dental students at [hidden text] through an elective subject, the knowledge index and conduct of these students are still not ideal. Thus, it is up to the coordination to create pedagogical strategies to incorporate this content in the curriculum to increase the level of knowledge of all students, social tolerance and reduce the levels of stigma with the student community.

\section{CONCLUSION}

The results suggest that UFPR dentistry students' knowledge and attitudes in relation to epilepsy need to be improved through approaches that aim to prepare the dentist to work in this area.

\section{RESUMO}

\section{Conhecimento e atitudes dos estudantes de um curso de Odontologia em relação à epilepsia}

A epilepsia é definida como um complexo de sintomas resultantes de diversas complicações neuronais que variam de alterações da consciência e da atividade motora até fenômenos sensoriais e comportamentos aberrantes. Esse problema de saúde tem sido associado a casos de estigma que podem repercutir seriamente na qualidade de vida do paciente. Este estudo teve por objetivo principal investigar o conhecimento e as atitudes em relação ao manejo de pacientes com diagnóstico de epilepsia dos estudantes de graduação do curso de Odontologia. A metodologia foi baseada na aplicação de um questionário estruturado com 17 perguntas fechadas que avaliaram informações como dados sociodemográficos, conhecimento sobre epilepsia e tolerância social. A amostra foi composta por 397 estudantes matriculados no curso de Odontologia da Universidade Federal do Paraná e dividida em: grupo 1, alunos cursando do $1^{\circ}$ até o $7^{\circ}$ semestre do curso e grupo 2 , alunos do último semestre do curso. Os estudantes do grupo 1 tiveram mais oportunidades para atender pacientes com epilepsia do que os do grupo 2. A maioria dos estudantes manifestou atitudes positivas em relação ao convívio com pessoas que sofrem de epilepsia e considerou que elas não poderiam exercer determinadas atividades profissionais. A questão com menor número de acertos tratava do tratamento de pacientes com a doença. O conhecimento dos estudantes em relação à epilepsia foi baixo. Porém, o nível de atitudes positivas em relação ao convívio com esse tipo de paciente foi considerado alto.

Descritores: Epilepsia. Conhecimento. Estigma Social. Estudantes de Odontologia. Inquéritos e 
Questionários.

\section{REFERENCES}

(1) Chang BS, Lowenstein DH. Epilepsy. N Engl J Med. 2003;349(13):1257-66.

(2) Fisher R, van Emde Boas W, Blume W, Elger C, Genton P, Lee P, Engel J. Epileptic seizures and epilepsy: definitions proposed by the International League Against Epilepsy (ILAE) and the International Bureau for Epilepsy (IBE). Epilepsia. 2005; 46(4):470-2.

(3) Magiorkinis E, Sidiropoulou K, Diamantis A. Hallmarks in the history of epilepsy: epilepsy in antiquity. Epilepsy Behav. 2010;17(1):103-8.

(4) Eade R, Chapman SC, Horne R, Balestrini S, Rush J, Sisodiya SM. Applying a perceptions and practicalities approach to understanding nonadherence to antiepileptic drugs. Epilepsia. 2015;56(9):1398-407.

(5) Thurman DJ, Beghi E, Begley CE, Berg AT, Buchhalter JR, Ding D, et al. Standards for epidemiologic studies and surveillance of epilepsy. Epilepsia. 2011; 52(7): 2-26.

(6) Brodie MJ, Elder AT, Kwan, P. Epilepsy in later life. Lancet Neurology. 2009; 8(11):101930.

(7) Holmes TR, Browne, GL. Handbook of epilepsy. $4^{\mathrm{a}}$ ed. Filadélfia: Lippincott Williams \& Wilkins. 2008.

(8) Cascino GD. Epilepsy: contemporary perspectives on evaluation and treatment. Mayo Clinic Proceedings. 1994; 69:1199-211.

(9) Berg, AT. Risk of recurrence after a first unprovoked seizure. Epilepsia. 2008; 49(1):138.

(10) Wyllie E. Wyllie's treatment of epilepsy: principles and practice. $5^{\mathrm{a}}$ ed. Filadélfia: Wolters Kluwer/Lippincott Williams \& Wilkins. 2010.

(11) Devlin AL, Odell M, Charlton J, Koppel S. Epilepsy and driving: current status of research. Epilepsy Research. 2012; 102(3):135-52.
(12) Newton, CR. Epilepsy in poor regions of the world. Lancet. 2012; 380(9848): 1193-201.

(13) Wilden JA, Cohen-Gadol AA. Evaluation of first nonfebrile seizures. American family physician. 2012; 86(4):334-40.

(14) Beghi E. The Epidemiology of epilepsy. Neuroepidemiology. 2020; 54(2):185-91.

(15) Falci SGM, Armond ACV. The Effectiveness of the Cold Therapy (cryotherapy) in the Management of Inflammatory Parameters after Removal of Mandibular Third Molars: A Meta-Analysis. Int Arch Otorhinolaryngol. 2019; 23(2):221-8.

(16) Hassona YM, Mahmoud AA, Ryalat SM, Sawair FA. Dental students knowledge and attitudes toward patients with epilepsy. Epilepsy \& Behavior. 2014;36:2-5.

(17) Aragon CE, Hess T, Burneo JG. Knowledge and attitudes about epilepsy: a survey of dentists in London, Ontario. J Can Dent Assoc. 2009; 75:450.

(18) Doshi D, Reddy BS, Kulkarni S, Karunakar PNA. Dentists knowledge, attitudes and practices toward patients with epilepsy in Hyderabad city, India. Epilepsy Behav. 2012; 23:447-450.

(19) Sharma PK, Misra AK, Chugh A, Chugh VK, Gonnade N, Singh S. Gingival hyperplasia: Should drug interaction be blamed for? Indian J Pharmacol. 2017; 49(3):257-259.

(20) Kartal A. Knowledge Of, Perceptions Of, Attitudes and Practices Regarding Epilepsy Among Medical Students in Turkey. Epilepsy Behav. 2016; 58:115-8.

\section{Correspondence to:}

Antonio Adilson Soares de Lima

e-mail: antollima@gmail.com

Department of Stomatology, Dentistry Course at

Federal University of Paraná

Prefeito Lothário Meissner 632 Campus Jardim Botânico

80210-170 Curitiba/PR, Brazil 